\title{
Transcriptional responses in the adaptation to ischaemia-reperfusion injury: a study of the effect of ischaemic preconditioning in total knee arthroplasty patients
}

\author{
Terence Murphy ${ }^{\dagger 1,2}$, Pauline M Walsh ${ }^{\dagger 1}$, Peter P Doran ${ }^{1}$ and Kevin J Mulhall*1,2
}

\begin{abstract}
Background: Ischaemic preconditioning (IPC) has emerged as a method of reducing ischaemia-reperfusion injury. However, the complex mechanism through which IPC elicits this protection is not fully understood. The aim of this study was to investigate the genomic response induced by IPC in muscle biopsies taken from the operative leg of total knee arthroplasty patients in order to gain insight into the IPC mechanism.

Methods: Twenty patients, undergoing primary total knee arthroplasty, were randomly assigned to IPC $(n=10)$ and control $(n=10)$ groups. Patients in the IPC group received ischaemic preconditioning immediately prior to surgery. IPC was induced by three five-minute cycles of tourniquet insufflation interrupted by five-minute cycles of reperfusion. A muscle biopsy was taken from the operative knee of control and IPC-treated patients at the onset of surgery and, again, at one hour into surgery. The gene expression profile of muscle biopsies was determined using the Affymetrix Human U113 2.0 microarray system and validated using real-time polymerase chain reaction (RT-PCR). Measurements of Creactive protein (CRP), erythrocyte sedimentation (ESR), white cell count (WCC), cytokines and haemoglobin were also made pre- and post-operatively.

Results: Microarray analysis revealed a significant increase in the expression of important oxidative stress defence genes, immediate early response genes and mitochondrial genes. Upregulation of pro-survival genes was also observed and correlated with a downregulation of pro-apoptotic gene expression. CRP, ESR, WCC, cytokine and haemoglobin levels were not significantly different between control and IPC patients.

Conclusions: The findings of this study suggest that IPC of the lower limb in total knee arthroplasty patients induces a protective genomic response, which results in increased expression of immediate early response genes, oxidative stress defence genes and pro-survival genes. These findings indicate that ischaemic preconditioning may be of potential benefit in knee arthroplasty and other musculoskeletal conditions.
\end{abstract}

\section{Background}

Ischaemic preconditioning has emerged as an extremely powerful method of protecting tissue against ischaemiareperfusion injury [1]. It is an innate protective mechanism that increases a tissue's tolerance to prolonged

\footnotetext{
* Correspondence: kjm@indigo.ie

1 UCD Clinical Research Centre, UCD School of Medicine and Medical Sciences, Mater University Hospital, Dublin, Ireland

† Contributed equally

Full list of author information is available at the end of the article
}

ischaemia when it is first subjected to short bursts of ischaemia and reperfusion. It is thought to provide this protection by increasing the tissue's tolerance to ischaemia, thereby reducing oxidative stress, inflammation and apoptosis in the preconditioned tissue. The protective effects of ischaemic preconditioning have been demonstrated in animal models $[2,3]$ and are now being investigated in human trials [4-8]. 
The complex mechanism through which IPC provides protection has only been partially elucidated. Studies have shown that IPC triggers the release of signalling molecules such as adenosine [3], bradykinin [9] and reactive oxygen species (ROS) [10]. The release of these molecules then activates protective signalling pathways involving kinases such as protein kinase C [11], PI-3K [12], tyrosine kinase [13] and MAPK kinases. This culminates in protection through reduced energy consumption, reduced oxidative stress, upregulation of heat shock proteins and inhibition of apoptosis with a resultant reduction in tissue injury.

Relatively little data describing the genomic response to ischaemic preconditioning in humans has been reported. Accordingly, we sought to investigate the effect of IPC in patients undergoing total knee arthroplasty. The primary objective of this study was to investigate the genomic response induced by IPC in muscle biopsies taken from the operative leg of total knee arthroplasty patients using microarray analysis. A secondary objective was to evaluate the effects of IPC on the systemic inflammatory response.

\section{Methods}

\section{Study design and patient selection}

Ethical approval for this study was granted by the ethics committee of the Cappagh National Orthopaedic Hospital, Dublin, Ireland. Informed consent was obtained from each patient before enrolment in the study. Patients undergoing primary knee arthroplasty $(n=20)$ were randomised to IPC $(\mathrm{n}=10)$ and control $(\mathrm{n}=10)$ groups, and patients were unaware of whether they were in the control or study group. Excluded from the study were (1) patients with abnormal ankle brachial indexes indicating poor vascular supply to the limb (2) patients with inflammatory arthropathies and (3) diabetic patients as there has been some correlation between oral sulphonurea therapy and preconditioning [14]. One patient was diagnosed with rheumatoid arthritis following recruitment and, therefore, was excluded from the study.

\section{Preconditioning protocol}

All patients had a tourniquet placed on the upper thigh of the operative limb after the administration of spinal anaesthesia as per normal protocol for knee arthroplasty surgery in our unit. The ischaemic preconditioning stimulus consisted of three five-minute periods of tourniquet insufflation on the upper thigh of the operative limb, interrupted by five minute periods of reperfusion. The pressure to which the tourniquet was insufflated for preconditioning was determined in relation to systolic blood pressure for each patient. The tourniquet was set $100 \mathrm{~mm}$ $\mathrm{Hg}$ above the patient's systolic BP to ensure ischaemic conditions. The control group simply had tourniquet insufflation as normal at the start of surgery. This preconditioning protocol has been used previously in human trials involving the upper and lower limb [15,16]. An overview of the experimental approach is provided in Figure 1.

\section{Blood sampling and serological analysis}

Pre-operative blood samples were collected as per routine protocol. Peripheral blood samples were obtained from the antecubital fossa of the upper limb at the initiation of surgery and at 1 hour of ischaemia to coincide with the muscle sampling. Blood was then obtained 30 min, 1 hour and 24 hours following tourniquet release to investigate the effect of reperfusion (Figure 1). Blood samples were centrifuged at $2000 \times \mathrm{g}$ for $15 \mathrm{~min}$ and the resulting serum samples were stored at $-80^{\circ} \mathrm{C}$. Serum samples were analysed for cytokine expression using the MSD Human Pro-Inflammatory 9-Plex Ultra-Sensitive Kit (Meso Scale Discovery, USA), according to the manufacturer's instructions. Blood samples were also analysed for haemoglobin, ESR, CRP and white cell count.

\section{Muscle sampling and RNA extraction}

Intra-operative sampling was used to obtain muscle biopsies from the quadriceps muscle. Muscle biopsies were taken from the operative knee at the immediate onset of surgery $(t=0)$, and again, at one hour into the surgery $(t=$ 1). Biopsies were rapidly frozen in liquid nitrogen and stored at $-80^{\circ} \mathrm{C}$. For extraction of total RNA, muscle biopsies $(\sim 100 \mathrm{mg})$ were added directly to a ceramic mortar containing liquid nitrogen and ground to a fine powder using a pestle. An aliquot of ice-cold TRI reagent (Sigma, Ireland) was added to the ground muscle powder, mixed using a vortex, and immediately homogenised on ice using a Polytron homogeniser (Kinematica, USA). Total RNA was isolated from the homogenised solution according to the manufacturer's instructions (Sigma, Ireland). RNA integrity was assessed using an Agilent 2100 Bioanalyser (Agilent Technologies, Germany).

\section{Affymetrix GeneChip hybridization, scanning and data analysis}

The gene expression profile of muscle biopsies taken from four control and four IPC-treated patients was determined using the Affymetrix Human U113 2.0 microarray system (Affymetrix, Santa Clara, CA). Sample amplification, labelling, hybridisation and detection were carried out by Almac Diagnostics, Craigavon, N. Ireland. Briefly, $2 \mu \mathrm{g}$ total RNA was reversed transcribed to cDNA, subjected to amplification and labelling followed by hybridisation to an array for $16-18$ hours at $45^{\circ} \mathrm{C}$. The array was then washed and stained with streptavidin- 


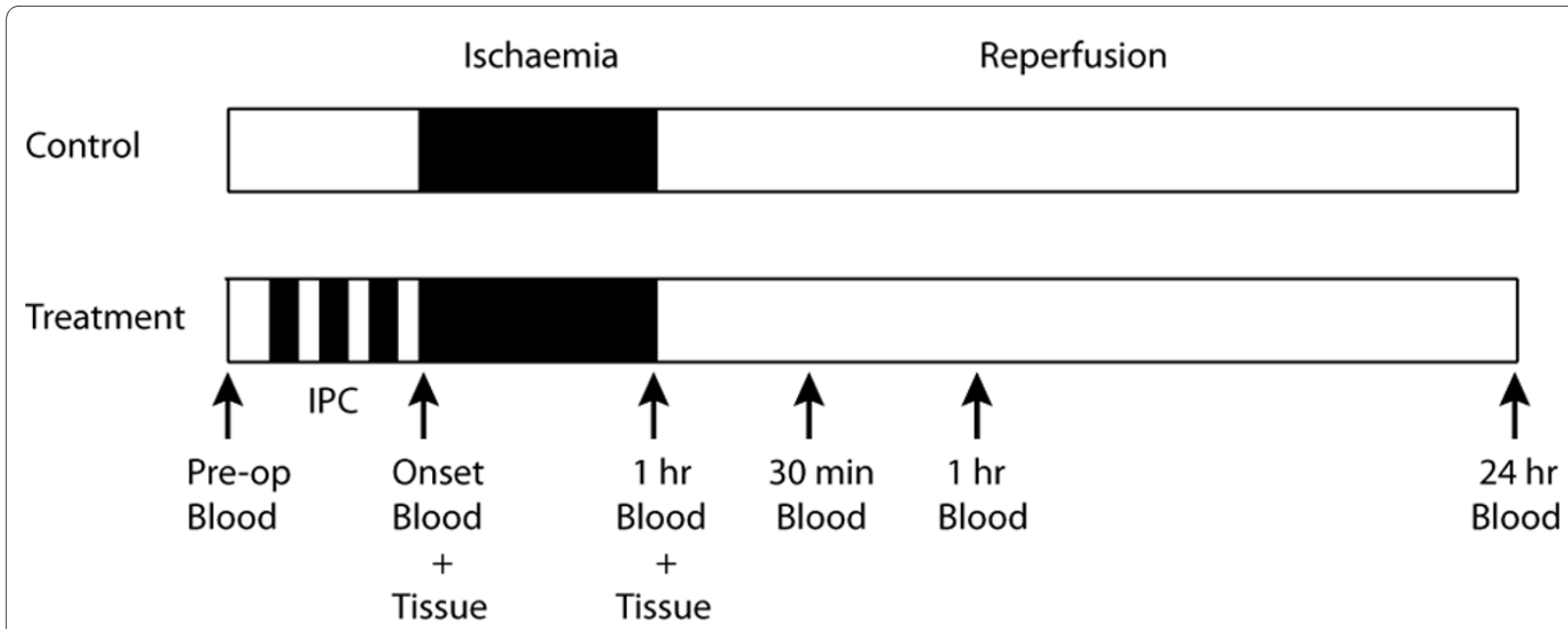

Figure 1 An overview of the study timeline and experimental approach.

phycoerythrin on the GeneChip Fluidics Station 450, and scanned using the GeneChip Scanner 3000. The Rosetta Error Model was applied to the raw data to generate intensity values. Gene filtering was then applied to identify significantly differentially regulated genes. Filters included: intensity p-value filter, background filter, fold change filter and signature p-value filter. Gene lists were analysed using DAVID 2.0 [17] and Ingenuity Pathway Analysis (Ingenuity Systems, http://www.ingenuity.com). The results of microarray analysis were validated by real-time PCR. The following 5 genes were validated by real-time PCR: early growth response 1 (egr1), cellular oncogene c-fos (fos), jun oncogene (jun), pyruvate dehydrogenase kinase $4(p d k 4)$ and heat shock

Table 1: Forward and reverse primers used for real-time PCR validation of microarray results

\begin{tabular}{ll}
\hline Gene & Primer Sequence \\
\hline EGR1 & F: 5'-AGCCCTACGAGCACCTGAC-3' \\
& R: 5'-AGCGGCCAGTATAGGTGATG-3' \\
PDK4 & F: 5'-GTCCCTACAATGGCACAAGG-3' \\
& R: 5'-GGTTCATCAGCATCCGAGTAG-3' \\
JUN & F: 5'-GAGCGGACCTATGGCTACA-3' \\
& R: 5'-TGAGGAGGTCCGAGTTCTT-3' \\
FOS & F: 5'-CAAGCGGAGACAGACCAAC-3' \\
& R: 5'-GAGCTGCCAGGATGAACTC-3' \\
HSPB8 & F: 5'-AGCCAGAGGAGTTGATGGTG-3' \\
& R: 5'-TGCAGGAAGCTGGATTTCT-3' \\
GAPDH & F: 5'-GAGTCAACGGATTTGGTCGT-3' \\
& R: 5'-TTGATTTGGAGGGATCTCG-3'
\end{tabular}

\footnotetext{
${ }^{*} F$, forward; $R$, reverse.
}

$22 \mathrm{kDa}$ protein 8 (hspb8). The nucleotide sequences of the primers used for real-time PCR are given in Table 1.

\section{Complementary DNA synthesis and real-time PCR}

Genomic DNA was removed from RNA samples using a DNA-free $e^{\text {Tu }}$ kit (Applied Biosystems, UK). RNA was then converted to complementary DNA (cDNA) using Enhanced Avian Reverse Transcriptase (Sigma). cDNA then served as template for Real-Time PCR, which was conducted using QIAGEN QuantiTect SYBR Green PCR kit. Gene expression was measured using absolute quantification, normalised to control and glyceraldehyde 3phosphate dehydrogenase (gapdh) expression resulting in mean fold change.

\section{Statistical Analysis}

Data are given as a mean $+/$ - standard deviation. Realtime PCR data were analysed by an unpaired $t$-test to determine a significant difference between sample means. Serological data were analysed by a one-sample ttest and a paired two-sample t-test. Differences were considered significant if $P<0.05$.

\section{Results}

To uncover the genomic response induced by ischaemic preconditioning, we analysed global gene expression levels in muscle biopsies taken from total knee arthroplasty patients using the Affymetrix Human U113 2.0 microarray system. Using RNA isolated from muscle biopsies taken from the operative leg at the immediate onset of surgery $(t=0)$, and again, at one hour into the surgery $(t=$ $1)$, the gene expression profiles of control and preconditioned patients were compared. The analysis of gene expression patterns at the onset of surgery allowed for the identification of changes resulting from the precondition- 


\begin{tabular}{lccc}
\hline & Control $(\mathbf{n}=\mathbf{9})$ & IPC $(\mathbf{n}=\mathbf{1 0})$ & $\boldsymbol{P}$ \\
\hline Age (years) & $70.8(+/-7.3)$ & $66.4(+/-9.6)$ & 0.28 \\
Sex ratio (M:F) & $2: 7$ & $6: 4$ & 0.61 \\
\hline
\end{tabular}

ing stimulus, which was performed immediately prior to surgery. The analysis of gene expression patterns at one hour into surgery permitted the identification of protective signalling, induced by IPC, which occurred at 1 hour into surgery.

All patients had an uneventful surgery and there were no adverse complications noted in the immediate postoperative period. There was no significant difference found between the two groups regarding patient demographics (Table 2). All patients underwent primary elective knee arthroplasty. None of the patients had any severe deformity or complicating clinical scenarios which required prolonged procedures to obtain good surgical outcome. The duration of tourniquet application time in all patients ranged from 68 to 87 minutes.

Differential gene expression at the onset of surgery $(t=0)$ Firstly, the changes in gene expression which occurred at the onset of surgery $(t=0)$ were analysed. This analysis revealed that 257 genes were significantly differentially regulated $>1.5$ fold in the IPC group as compared to the

A

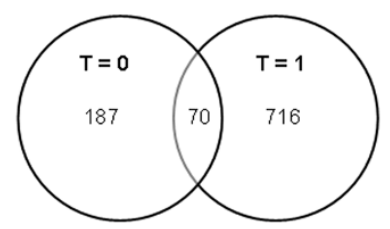

B

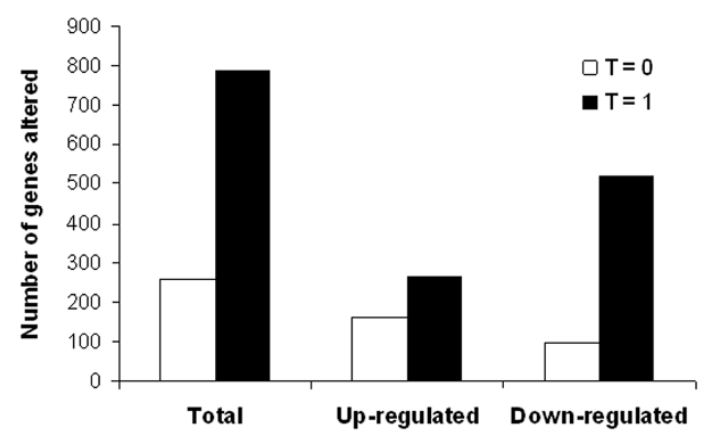

Figure 2 Analysis of microarray data. (A) Venn diagram depicting the overlap of differentially expressed genes at the onset of surgery ( $t$ $=0$ ) and at 1 hour into surgery $(t=1)$. (B) Numbers of genes demonstrating a minimum of 1.5 fold-change in expression at the two timepoints studied. control group. Of these 257 genes, 162 genes were upregulated $>1.5$ fold while 95 genes were downregulated $>1.5$ fold (Figure 2). Gene ontology (GO) analysis was performed to gain a comprehensive understanding of the gene classes that were differentially regulated in the IPC group. Genes were analyzed by their GO annotations, including biological process, molecular function and cellular component categories. Ontology analysis, preformed using DAVID 2.0 revealed an upregulation of genes relating to metabolic processes, mitochondrial biogenesis/organisation and response to stress at this timepoint (Figure 3 and Table 3 ).

\section{Differential gene expression at 1 hour into surgery $(t=1)$}

We next analysed those genes that were differentially regulated at 1 hour into surgery $(t=1)$. These data revealed a significantly higher number of differentially regulated genes compared to the onset of surgery (Figure 2). A total of 786 genes were differentially expressed $>1.5$ fold at this time point, 519 genes were downregulated while 267 genes were up-regulated (Figure 2). Ontology analysis revealed a downregulation in genes related to cell communication, developmental processes, cell adhesion and cell proliferation (Figure 3). An upregulation in the expression of genes related to the regulation of metabolic processes, biological processes and gene expression was observed (Figure 3). Increased expression of genes involved in the response to stress including oxidative stress, and the regulation of cell death was also observed (Table 4).

\section{Validation of microarray analysis using real-time PCR}

The results of microarray analysis were validated by realtime PCR in an additional 4 patients. Real-time PCR was performed on five selected genes (egr $1, f o s, p d k 4$, jun, and hspb8), a number of which have previously been associated with the ischaemic preconditioning mechanism, i.e. egr1, fos and jun. Expression analysis of the five chosen genes by real-time PCR correlated with our array data, and showed that the expression levels of egr 1, fos and $p d k 4$ in control and preconditioned samples were significantly different when analysed by both methods (Figure 4). 


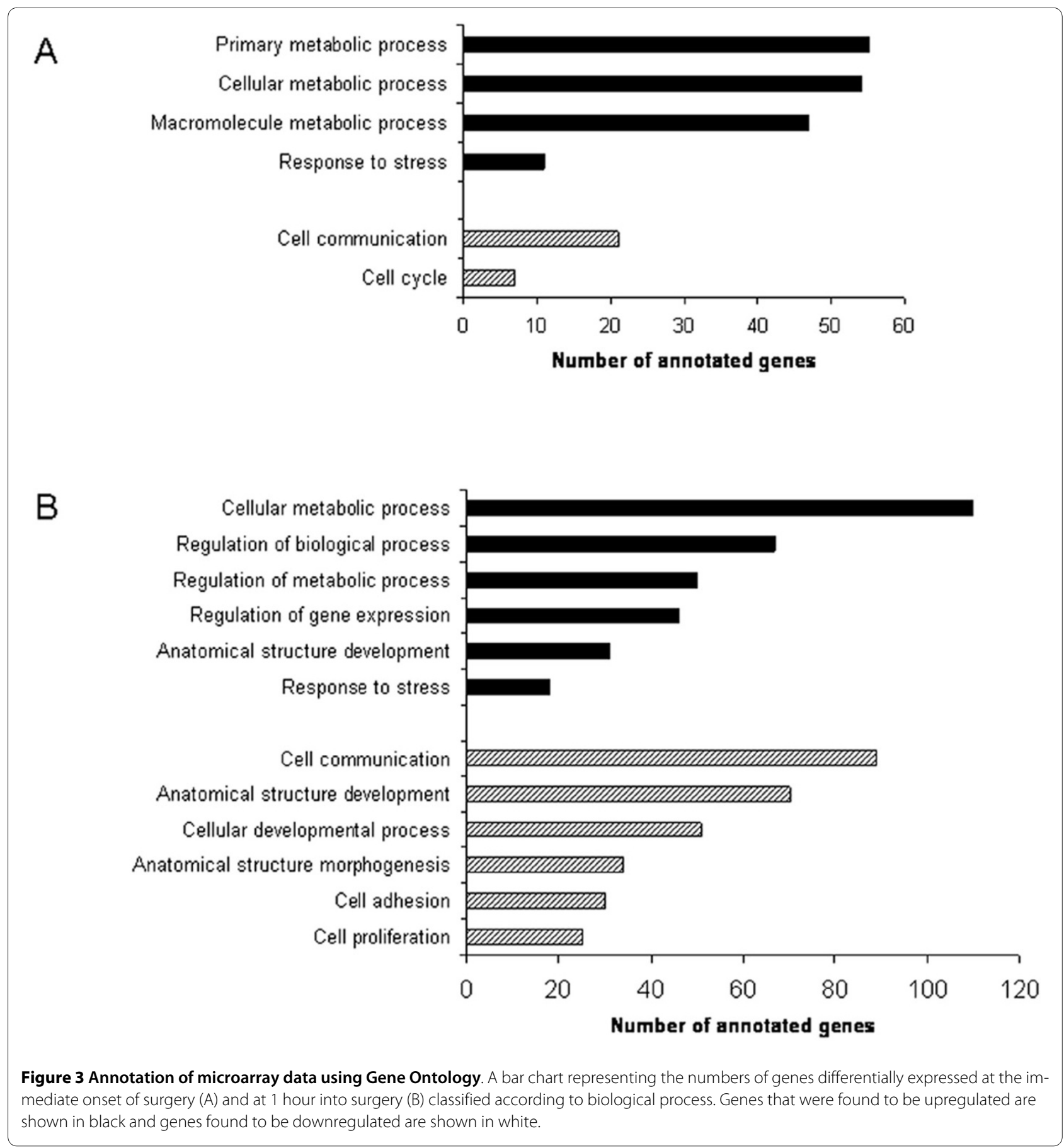

\section{Systemic effects of IPC}

No statistically significant difference was found between the control and treatment groups with regard to circulating levels of CRP, ESR and white blood cell count (Figure $5 \mathrm{~A}, \mathrm{~B}, \mathrm{C})$. There was a reduction in haemoglobin loss in the treatment group at 24 hours post-reperfusion but this reduction was not statistically significant $(\mathrm{p}<0.081$; Figure 5D). Mean levels of the pro-inflammatory cytokines
IL-8, TNF-alpha, INF-gamma, IL-1-beta, IL-2, IL-10, IL12p70, GM-CSF were also measured and again no statistically significant differences were demonstrated. IL-6 levels were significantly increased at $30 \mathrm{~min}(1.35 \mathrm{pg} / \mathrm{ml} \pm$ $1.7, \mathrm{p}<0.037)$ and 1 hour $(3.11 \mathrm{pg} / \mathrm{ml} \pm 3.25, \mathrm{p}<0.014)$ post-reperfusion in the control group, and at 24 hours post-reperfusion in both groups (control $95.1 \mathrm{pg} / \mathrm{ml} \pm$ 56.4, 95\%, $\mathrm{p}<0.0005$; treatment $67.5 \mathrm{pg} / \mathrm{ml} \pm 37.8, \mathrm{p}<$ 
Table 3: Genes up-regulated in IPC patients compared to control patients at the onset of surgery $(t=0)$

\begin{tabular}{|c|c|c|c|c|}
\hline Gene name & Symbol & Public ID & Fold change & $P$ \\
\hline \multicolumn{5}{|l|}{ Mitochondrial } \\
\hline $\begin{array}{l}\text { COX18 cytochrome c } \\
\text { oxidase assembly } \\
\text { homolog }\end{array}$ & $\operatorname{CoX} 18$ & Al769476 & 1.71 & 0.036 \\
\hline $\begin{array}{l}\text { COX11 cytochrome c } \\
\text { oxidase assembly } \\
\text { homolog }\end{array}$ & $\operatorname{cox} 11$ & Al376724 & 1.87 & 0.008 \\
\hline Uncoupling protein 3 & UCP3 & NM_003356 & 1.99 & 0.037 \\
\hline $\begin{array}{l}\text { Translocase of inner } \\
\text { mitochondrial } \\
\text { membrane } 10\end{array}$ & TIMM10 & AF152354 & 1.54 & 0.001 \\
\hline $\begin{array}{l}\text { Mitochondrial ribosomal } \\
\text { protein } L 43\end{array}$ & MRPL43 & N74662 & 1.90 & 0.007 \\
\hline $\begin{array}{l}\text { Pyruvate dehydrogenase } \\
\text { kinase } 4\end{array}$ & PDK4 & AL832708 & 3.57 & 0.022 \\
\hline \multicolumn{5}{|l|}{ Other } \\
\hline $\begin{array}{l}\text { BCL2/adenovirus E1B } 19 \\
\text { kDa interacting protein } 1\end{array}$ & BNIP1 & NM_013979 & 1.55 & 0.001 \\
\hline
\end{tabular}

${ }^{*}$ A positive number indicates elevated expression (fold change) in skeletal muscle tissue of IPC-treated patient compared to skeletal muscle tissue of control patient.

0.0005). The mean IL-6 level in the control group at 24 hours of reperfusion was higher than that of the IPC group $(95.1 \mathrm{pg} / \mathrm{ml} \pm 56.4 \mathrm{v} 67.5 \mathrm{pg} / \mathrm{ml} \pm 37.8)$, however, this difference was not statistically significant (Figure $5 \mathrm{E}$ ).

\section{Discussion}

Ischaemic preconditioning has been shown to protect against ischaemia-reperfusion injury in both animal models and human studies $[1,3,15,18]$, however, the signalling mechanisms responsible remain unclear. To date, relatively little data describing the genomic response to ischaemic preconditioning in humans has been reported. Therefore, to identify the genomic response induced by ischaemic preconditioning, we analysed gene expression patterns in a cohort of total knee arthroplasty patients using the Affymetrix Human U113 2.0 microarray system.

While such a cohort of patients is unlikely to develop serious complications of ischaemia-reperfusion, this study provided a model for investigating the local and systemic effects of ischaemic preconditioning, as standard practice for total knee arthroplasty in our institution already involves the application of a tourniquet for the duration of the operation. In this study, ischaemic preconditioning was induced by three five-minute cycles of tourniquet insufflation on the operative lower limb interrupted by five-minute cycles of reperfusion; this precon- ditioning protocol has previously been shown to be effective in other clinical studies [15,16].

We investigated the mechanism of local IPC by comparing the gene expression profile of muscle biopsies taken from the operative leg of control and IPC-treated patients using microarray analysis. IPC was found to induce a gene expression profile which was indicative of a protective genomic response in muscle biopsies taken from IPC-treated patients. A comparison of the gene expression profiles of the control and IPC groups indicated that the effect of ischaemic preconditioning was correlated with increased expression of genes involved in immediate early response, defence against oxidative stress, pro-survival functions, and a decrease in gene expression associated with cell death.

\section{IPC triggers the expression of early response genes}

In the present study, increased expression of immediate early response genes was shown to be associated with the protective response induced by IPC. This was exemplified by an upregulation in the expression of egr1, ier $2, c$ fos, $c$-jun and $m y c$. Immediate early response genes are a group of genes that are activated transiently and rapidly in response to a wide variety of cellular stimuli. Furthermore, a number of these genes have previously been reported to be involved in the adaptation to ischaemia and in the IPC mechanism $[19,20]$. In a rat model of IPC, 
Table 4: Genes up- or down-regulated in IPC patients compared to control patients at 1 hour into surgery $(t=1)$

\begin{tabular}{|c|c|c|c|c|}
\hline Gene name & Gene symbol & Public ID & Fold change & $P$ \\
\hline \multicolumn{5}{|l|}{ Immediate early genes } \\
\hline Early growth response 1 & EGR1 & AV733950 & 2.84 & 0.001 \\
\hline $\begin{array}{l}\text { Myc proto oncogene } \\
\text { protein }\end{array}$ & MYC & NM_002467 & 2.58 & 0.038 \\
\hline Cellular oncogene c-fos & FOS & BC004490 & 2.11 & 0.018 \\
\hline Immediate early response 2 & IER2 & NM_004907 & 1.58 & 0.034 \\
\hline Jun oncogene & JUN & BC002646 & 1.43 & 0.001 \\
\hline \multicolumn{5}{|l|}{ Oxidative stress defence } \\
\hline Catalase & CAT & AU147084 & 2.14 & 0.017 \\
\hline $\begin{array}{l}\text { Glutathione S-transferase } \\
\text { theta } 1\end{array}$ & GSTT1 & AL359937 & 2.69 & 0.025 \\
\hline Sequestosome 1 & SQSTM1 & AW293441 & 2.04 & 0.018 \\
\hline \multicolumn{5}{|l|}{ Chaperone/Survival } \\
\hline $\begin{array}{l}\text { DnaJ (Hsp40) homolog, } \\
\text { subfamily B, member } 6\end{array}$ & DNAJB6 & AF080569 & 1.45 & 0.042 \\
\hline Heat shock 22 kDa protein 8 & HSPB8 & BF109740 & 1.83 & 0.001 \\
\hline $\begin{array}{l}\text { BCL2/adenovirus E1 B } 19 \\
\text { kDa interacting protein } 1\end{array}$ & BNIP1 & NM_013979 & 1.50 & 0.004 \\
\hline BCL6 co-repressor & BCOR & AF317391 & 1.74 & 0.047 \\
\hline \multicolumn{5}{|l|}{ Anti-apoptotic } \\
\hline Caspase 8 & CASP8 & BF439983 & -2.00 & 0.045 \\
\hline Caspase 7 & CASP7 & NM_001227 & -1.31 & 0.026 \\
\hline \multicolumn{5}{|l|}{ Mitochondrial } \\
\hline Uncoupling protein 3 & UCP3 & NM_003356 & 2.41 & 0.001 \\
\hline $\begin{array}{l}\text { Pyruvate dehydrogenase } \\
\text { kinase } 4\end{array}$ & PDK4 & AL832708 & 2.99 & 0.009 \\
\hline
\end{tabular}

${ }^{*}$ A positive number indicates elevated expression (fold change) in skeletal muscle tissue of IPC-treated patient compared to skeletal muscle tissue of control patient. A negative number indicates decreased expression (fold change) in skeletal muscle tissue of IPC-treated patient compared to skeletal muscle tissue of control patient.

increased expression of $c$-fos and myc was found to be associated with cardioprotection as evidenced by improved ventricular function and reduced infarct size [19]. More recently, increased expression of egrl was associated with a predicted cardioprotective phenotype induced by intraoperative ischaemia-reperfusion [21]. The high incidence of early response gene expression indicates that the induction of these genes may be an important element of the protective response induced by IPC.

\section{IPC induces stress response and prosurvival gene expression}

The cytoprotective abilities of anti-oxidant proteins induced by IPC are well documented in in vitro and animal models $[19,22,23]$. In the present study, microarray analysis revealed increased expression of anti-oxidant genes in IPC-treated patients following one hour of ischaemia, including catalase and glutathione S-transferase theta 1. Increased ROS generation occurs in ischaemic tissue upon reperfusion. An important element of the cellular defence against ROS is the induction of 


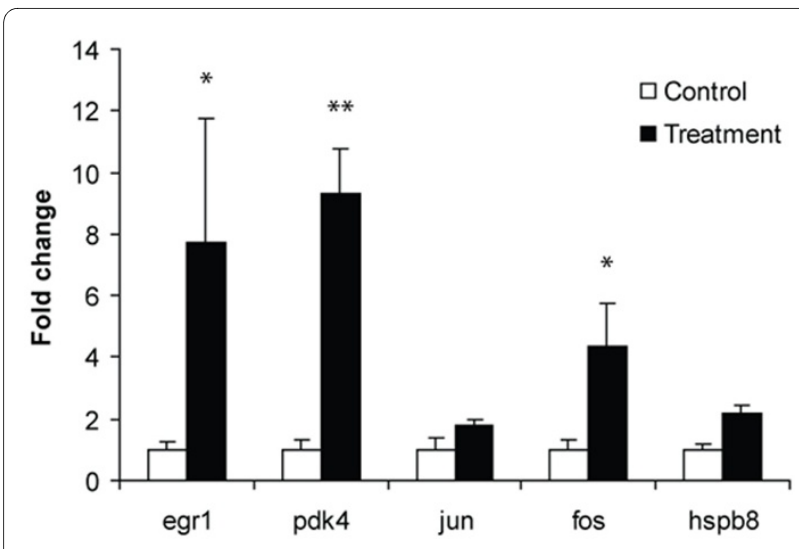

Figure $\mathbf{4}$ Validation of microarray data using RT-PCR. Gene expression patterns of five selected genes in skeletal muscle biopsies of control and preconditioned patients as determined by RT-PCR. Values are the mean fold difference from control. ${ }^{*}=\mathrm{P}<0.05 ;{ }^{* *}=\mathrm{P}<0.01$ for control group versus IPC group.

antioxidant enzymes and detoxifying enzymes such as catalase and glutathione S-transferase. Catalase functions in the decomposition of hydrogen peroxide to water and oxygen while glutathione S-transferases catalyze the conjugation of reduced glutathione to a variety of electrophilic and hydrophobic compounds. Nuclear factorerythroid 2-related factor 2 (Nrf2) is a transcription factor and an important regulator of the cells response to oxidative stress [24]. It regulates the expression of a network of cytoprotective enzymes and has recently been shown to be involved in the ischaemic preconditioning mechanism $[25,26]$. Pathway analysis revealed induction of a number genes involved in Nrf2 signalling in IPCtreated patients, including catalase, glutathione S-transferase, sequestosome 1, jun and fos. Nrft2 signalling has recently been shown to protect against ischaemia-reperfusion injury in both a kidney cell line and in liver biopsies $[25,26]$. Results of our study give further support to the idea that Nrf2 signalling is an important protective signalling pathway activated by IPC.

Analysis of microarray data demonstrated increased expression of genes with pro-survival or chaperone functions in IPC patients. Increased expression of heat shock protein $22 \mathrm{kDa}$ protein 8, BCL2/adenovirus E1B $19 \mathrm{kDa}$ interacting protein 1 , and BCL6 co-repressor and DnaJ (Hsp40) homolog, subfamily B, member 6 was observed in IPC-treated patients. Studies have shown that heat shock proteins play a key role in the protection provided by IPC, in particular HSP70 and HSP27 [27-29]. The induction of pro-survival gene expression was also associated with a reduction in pro-apoptotic gene expression (caspase 7 and 8) suggesting that IPC may modulate both cell survival and cell death pathways.

\section{The systemic effect of IPC}

Ischaemic preconditioning, induced by transient ischaemia of a limb, has been shown to protect remote organs against the effects of ischaemia-reperfusion injury $[15,18,30]$. In a study of children undergoing cardiopulmonary bypass surgery, patients that received remote IPC (via transient ischaemia of the leg) had less cardiac and pulmonary insult [18]. Similarly, in adult patients, decreased serum troponin levels were detected after cardiopulmonary bypass surgery in those patients that received remote IPC via transient ischaemia of the upper arm [15]. It has also been proposed that remote preconditioning may protect against ischaemia-reperfusion injury through a potent suppression of inflammatory signals. Evidence to support this has been demonstrated in healthy volunteers where ischaemic preconditioning of the upper arm has been shown to provide remote protection in the form of reduced inflammatory cell activation and reduced endothelial dysfunction in the contralateral arm [31], and to suppress pro-inflammatory gene expression in circulating leukocytes [32].

In this study, we investigated the effect of ischaemic preconditioning on the systemic inflammatory response to ischaemia-reperfusion in our cohort of total knee arthroplasty patients $(n=20)$. While the patients in this cohort were unlikely to suffer serious complications of ischaemia-reperfusion, a statistically significant increase in the circulating levels of IL- 6 was observed in both groups at 24 hours post-reperfusion indicating a postoperative systemic inflammatory response occurred in both patient groups. While skeletal muscle is relatively resistant to ischaemic-reperfusion injury, studies have shown that tourniquet-induced ischaemia-reperfusion leads to systemic activation of PMNs and T cells $[16,30]$. In the present study, no significant difference in the mean levels of circulating cytokines was observed between patient groups. However, IPC patients had a tendency for a reduction in IL-6 and ESR at 24 hours post-reperfusion indicating that IPC may attenuate the post-operative inflammatory response in these patients. Other studies have shown that a local IPC stimulus, induced via transient ischaemia of the lower limb, can modulate the systemic inflammatory response following ischaemicreperfusion in a rat model of limb ischaemic-reperfusion and in patients undergoing cruciate ligament reconstruction $[16,30]$. While these studies, and the current study, have shown that local IPC exerts distant anti-inflammatory effects, it is important to note that local and remote IPC are two separate forms of preconditioning and that the signalling mechanisms underlying both forms are not entirely similar. 
A

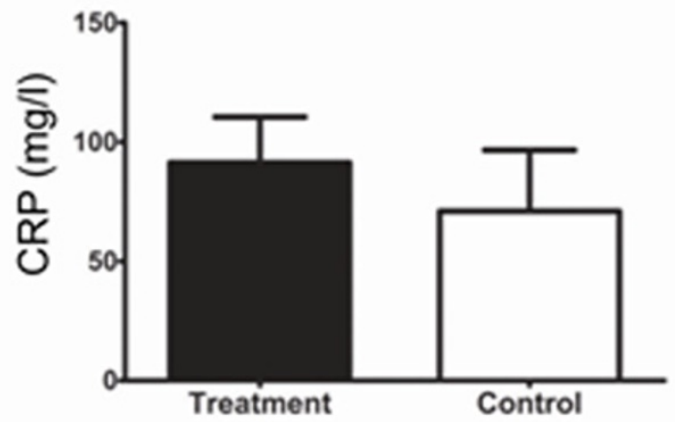

C

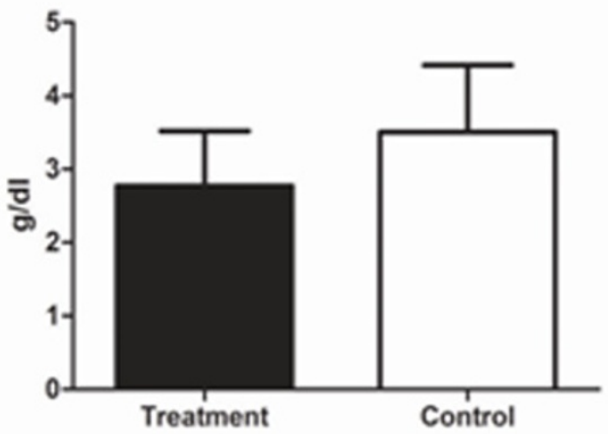

B

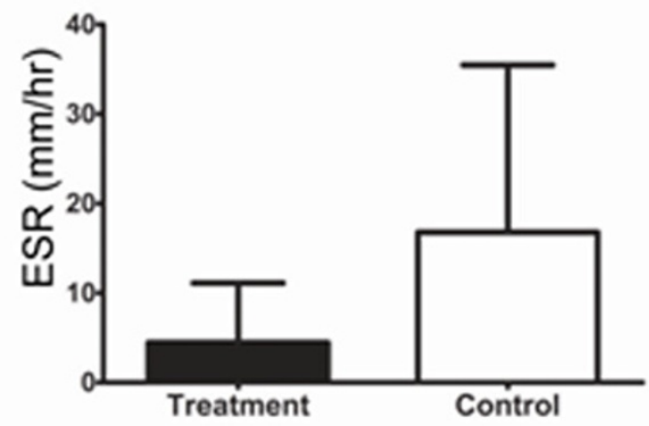

D

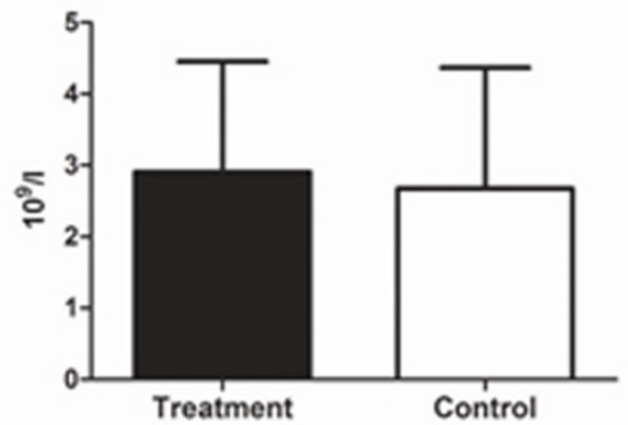

$E$

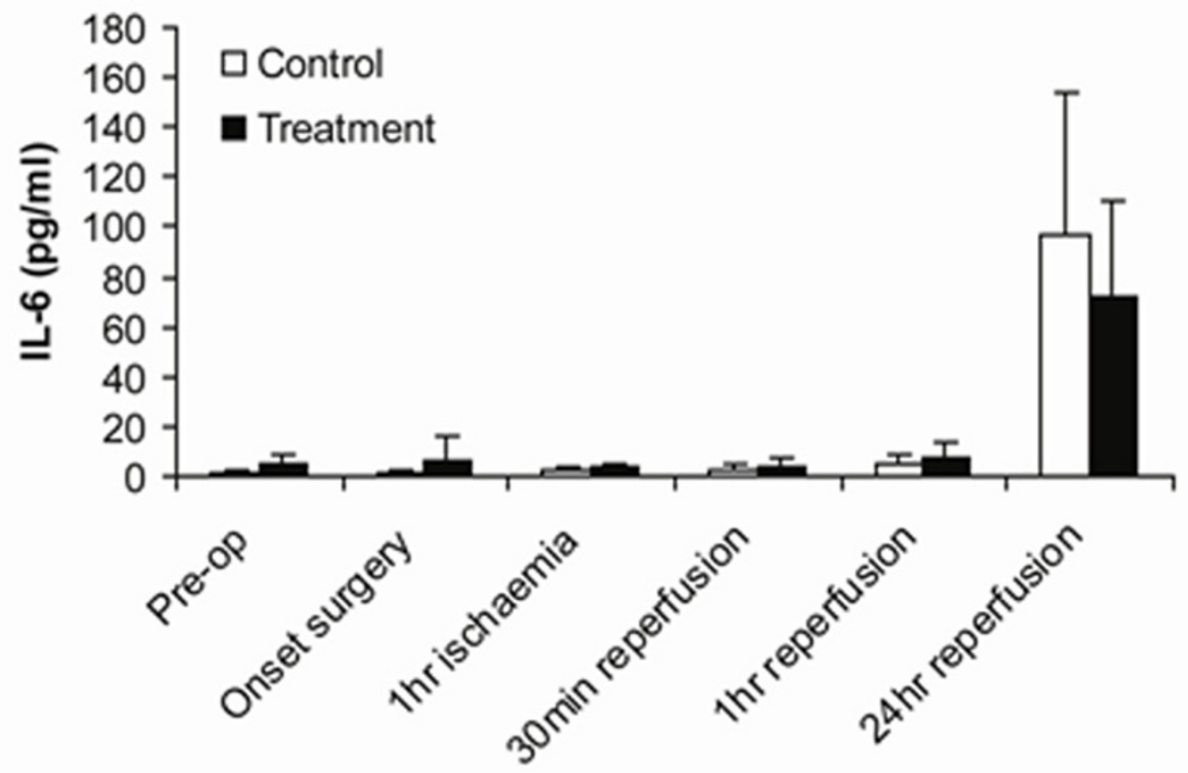

Figure 5 Analysis of serological data. Changes in the level of CRP (A), ESR (B), haemoglobin (C) and WCC (D) in control and ischaemic preconditioned patients at 24 hours post-surgery. Pre-, intra- and post-operative levels of IL-6 in control and preconditioned patients (E). Data are represented as means $+/$ - the standard deviation. 


\section{Conclusions}

In summary, the findings of this study show that IPC induces a protective genomic response in total knee arthroplasty patients. The protective effect of IPC was associated with increased expression of genes involved in immediate early response, defence against oxidative stress and pro-survival functions. This study also served as a pilot study to demonstrate the safety of this technique in TKA patients. Results of this study indicate that IPC may be of potential benefit in this and other musculoskeletal conditions.

\section{Competing interests}

The authors declare that they have no competing interests.

\section{Authors' contributions}

TM, PPD and KJM conceived and designed the experiments. TM performed the preconditioning protocol and collected patient samples. TM and PMW carried out the experimental work including the extraction of RNA, validation of microarray data by real-time PCR and the analysis of serum samples. The microarray experiment and the analysis of array data were carried out by Almac Diagnostics, Craigavon, N. Ireland. PMW was responsible for the annotation of the microarray data and the preparation of the manuscript. All authors read and approved the final manuscript.

\section{Acknowledgements}

This study was supported by a Postgraduate Education and Research grant from the Mater College, Dublin, Ireland. The funding body had no input into the design, implementation or publication of the study. The authors thank Dr. David Murray for his help with the annotation of array data.

\section{Author Details}

1 UCD Clinical Research Centre, UCD School of Medicine and Medical Sciences, Mater University Hospital, Dublin, Ireland and ${ }^{2}$ Cappagh National Orthopaedic Hospital, Dublin, Ireland

Received: 26 February 2010 Accepted: 10 May 2010

Published: 10 May 2010

\section{References}

1. Murry CE, Jennings RB, Reimer KA: Preconditioning with ischemia: a delay of lethal cell injury in ischemic myocardium. Circulation 1986, 74(5):1124-1136.

2. Papanastasiou S, Estdale SE, Homer-Vanniasinkam S, Mathie RT: Protective effect of preconditioning and adenosine pretreatment in experimental skeletal muscle reperfusion injury. Br J Surg 1999, 86(7):916-922.

3. Liu GS, Thornton J, Van Winkle DM, Stanley AW, Olsson RA, Downey JM: Protection against infarction afforded by preconditioning is mediated by $\mathrm{A} 1$ adenosine receptors in rabbit heart. Circulation 1991 , 84(1):350-356.

4. Jenkins DP, Pugsley WB, Alkhulaifi AM, Kemp M, Hooper J, Yellon DM: Ischaemic preconditioning reduces troponin T release in patients undergoing coronary artery bypass surgery. Heart 1997, 77(4):314-318.

5. Clavien PA, Selzner M, Rudiger HA, Graf R, Kadry Z, Rousson V, Jochum W: A prospective randomized study in 100 consecutive patients undergoing major liver resection with versus without ischemic preconditioning. Ann Surg 2003, 238(6):843-850. discussion 851-842.

6. Petrowsky H, McCormack L, Trujillo M, Selzner M, Jochum W, Clavien PA: A prospective, randomized, controlled trial comparing intermittent portal triad clamping versus ischemic preconditioning with continuous clamping for major liver resection. Ann Surg 2006, 244(6):921-928. discussion 928-930.

7. Yang Y, Chen SX, Zhang WX: [Effect of ischemic preconditioning on human lung cell apoptosis in vivo and the expression of regulating gene bcl-2]. Hunan Yi Ke Da Xue Xue Bao 2002, 27(1):43-45.

8. Teoh LK, Grant R, Hulf JA, Pugsley WB, Yellon DM: The effect of preconditioning (ischemic and pharmacological) on myocardial necrosis following coronary artery bypass graft surgery. Cardiovasc Res 2002, 53(1):175-180.

9. Goto M, Liu Y, Yang XM, Ardell JL, Cohen MV, Downey JM: Role of bradykinin in protection of ischemic preconditioning in rabbit hearts. Circ Res 1995, 77(3):611-621.

10. Baines $C P$, Goto M, Downey JM: Oxygen radicals released during ischemic preconditioning contribute to cardioprotection in the rabbit myocardium. J Mol Cell Cardiol 1997, 29(1):207-216.

11. Ytrehus K, Liu Y, Downey JM: Preconditioning protects ischemic rabbit heart by protein kinase C activation. Am J Physiol 1994, 266(3 Pt 2):H1145-1152.

12. Tong H, Chen W, Steenbergen C, Murphy E: Ischemic preconditioning activates phosphatidylinositol-3-kinase upstream of protein kinase $C$. Circ Res 2000, 87(4):309-315.

13. Tong H, Imahashi K, Steenbergen C, Murphy E: Phosphorylation of glycogen synthase kinase-3beta during preconditioning through a phosphatidylinositol-3-kinase--dependent pathway is cardioprotective. Circ Res 2002, 90(4):377-379.

14. Cleveland JC Jr, Meldrum DR, Cain BS, Banerjee A, Harken AH: Oral sulfonylurea hypoglycemic agents prevent ischemic preconditioning in human myocardium. Two paradoxes revisited. Circulation 1997 96(1):29-32.

15. Hausenloy DJ, Mwamure PK, Venugopal V, Harris J, Barnard M, Grundy E, Ashley E, Vichare S, Di Salvo C, Kolvekar S, Hayward M, Keogh B, MacAllister RJ, Yellon DM: Effect of remote ischaemic preconditioning on myocardial injury in patients undergoing coronary artery bypass graft surgery: a randomised controlled trial. Lancet 2007, 370(9587):575-579.

16. Sullivan PJ, Sweeney KJ, Hirpara KM, Malone CB, Curtin W, Kerin MJ: Cyclical ischaemic preconditioning modulates the adaptive immune response in human limb ischaemia-reperfusion injury. Br J Surg 2009, 96(4):381-390

17. Dennis G Jr, Sherman BT, Hosack DA, Yang J, Gao W, Lane HC, Lempicki RA: DAVID: Database for Annotation, Visualization, and Integrated Discovery. Genome Biol 2003, 4(5):P3.

18. Cheung MM, Kharbanda RK, Konstantinov IE, Shimizu M, Frndova H, Li J, Holtby HM, Cox PN, Smallhorn JF, Van Arsdell GS, Redington AN: Randomized controlled trial of the effects of remote ischemic preconditioning on children undergoing cardiac surgery: first clinical application in humans. J Am Coll Cardiol 2006, 47(11):2277-2282.

19. Das DK, Engelman RM, Kimura Y: Molecular adaptation of cellular defences following preconditioning of the heart by repeated ischaemia. Cardiovasc Res 1993, 27(4):578-584.

20. Aebert H, Cornelius T, Ehr T, Holmer SR, Birnbaum DE, Riegger GA, Schunkert $\mathrm{H}$ : Expression of immediate early genes after cardioplegic arrest and reperfusion. Ann Thorac Surg 1997, 63(6):1669-1675.

21. Arab S, Konstantinov IE, Boscarino C, Cukerman E, Mori A, Li J, Liu PP, Redington AN, Coles JG: Early gene expression profiles during intraoperative myocardial ischemia-reperfusion in cardiac surgery. $J$ Thorac Cardiovasc Surg 2007, 134(1):74-81. 81 e71-72.

22. Li Q, Bolli R, Qiu Y, Tang XL, Guo Y, French BA: Gene therapy with extracellular superoxide dismutase protects conscious rabbits against myocardial infarction. Circulation 2001, 103(14):1893-1898.

23. Yamashita N, Nishida M, Hoshida S, Kuzuya T, Hori M, Taniguchi N, Kamada $\mathrm{T}$, Tada M: Induction of manganese superoxide dismutase in rat cardiac myocytes increases tolerance to hypoxia 24 hours after preconditioning. J Clin Invest 1994, 94(6):2193-2199.

24. Jaiswal AK: Nrf2 signaling in coordinated activation of antioxidant gene expression. Free Radic Biol Med 2004, 36(10):1199-1207.

25. Leonard MO, Kieran NE, Howell K, Burne MJ, Varadarajan R, Dhakshinamoorthy S, Porter AG, O'Farrelly C, Rabb H, Taylor CT: Reoxygenation-specific activation of the antioxidant transcription factor Nrf2 mediates cytoprotective gene expression in ischemiareperfusion injury. Faseb J 2006, 20(14):2624-2626.

26. Calvert JW, Jha S, Gundewar S, Elrod JW, Ramachandran A, Pattillo CB, Kevil CG, Lefer DJ: Hydrogen sulfide mediates cardioprotection through Nrf2 signaling. Circ Res 2009, 105(4):365-374.

27. Das DK, Maulik N: Cardiac genomic response following preconditioning stimulus. Cardiovasc Res 2006, 70(2):254-263.

28. Guisasola MC, Desco Mdel M, Gonzalez FS, Asensio F, Dulin E, Suarez A, Garcia Barreno P: Heat shock proteins, end effectors of myocardium ischemic preconditioning? Cell Stress Chaperones 2006, 11(3):250-258. 
29. Efthymiou CA, Mocanu MM, de Belleroche J, Wells DJ, Latchmann DS, Yellon DM: Heat shock protein 27 protects the heart against myocardial infarction. Basic Res Cardiol 2004, 99(6):392-394.

30. Szabo A, Varga R, Keresztes M, Vizler C, Nemeth I, Razga Z, Boros M: Ischemic limb preconditioning downregulates systemic inflammatory activation. J Orthop Res 2009, 27(7):897-902

31. Kharbanda RK, Peters M, Walton B, Kattenhorn M, Mullen M, Klein N, Vallance P, Deanfield J, MacAllister R: Ischemic preconditioning prevents endothelial injury and systemic neutrophil activation during ischemiareperfusion in humans in vivo. Circulation 2001, 103(12):1624-1630.

32. Konstantinov IE, Arab S, Kharbanda RK, Li J, Cheung MM, Cherepanov V, Downey GP, Liu PP, Cukerman E, Coles JG, Redington AN: The remote ischemic preconditioning stimulus modifies inflammatory gene expression in humans. Physiol Genomics 2004, 19(1):143-150.

doi: $10.1186 / 1479-5876-8-46$

Cite this article as: Murphy et al., Transcriptional responses in the adaptation to ischaemia-reperfusion injury: a study of the effect of ischaemic preconditioning in total knee arthroplasty patients Journal of Translational Medicine 2010, 8:46

Submit your next manuscript to BioMed Central and take full advantage of:

- Convenient online submission

- Thorough peer review

- No space constraints or color figure charges

- Immediate publication on acceptance

- Inclusion in PubMed, CAS, Scopus and Google Scholar

- Research which is freely available for redistribution

Submit your manuscript at www.biomedcentral.com/submit
C Biomed Central 